\title{
FORMULASI STRATEGI PEMASARAN LEMBAGA AMIL ZAKAT NASIONAL YAYASAN YATIM MANDIRI
}

\author{
Bimo Wahju Wardojo \\ Mahasiswa Program Studi S2 Magister Manajemen - Fakultas Ekonomi dan Bisnis \\ Universitas Airlangga \\ e-mail: bimosby14@gmail.com
}

\begin{abstract}
In the past five years (2014-2018) LAZNAS Yatim Mandiri experienced: (1) the growth rate of LAZNAS Yatim Mandiri donation growth decreased from two digits to only one digit; (2) declining market share of LAZNAS Yatim Mandiri donations; (3) the low growth rate of LAZNAS Yatim Mandiri donation collection in the last five years has been $8 \%$ compared to the average growth rate of zakat nationally (25.79\%). This study aims to design the right marketing strategy formulation for LAZNAS Yatim Mandiri to increase market share in the competitive era by using diamond strategy frame work. The research method used in research is a qualitative approach, namely case studies. Data collection uses literature study and in-depth interviews. The results of this study recommend the marketing strategy formulation based on the diamond strategy framework including arenas, vehicles, differentiators, staging, and economic logic.
\end{abstract}

Keywords: marketing strategy formulations, amil zakat institutions, diamond strategies

\section{A. PENDAHULUAN}

Mayoritas penduduk Indonesia adalah muslim dengan sejumlah 216,66 juta penduduk atau jika dipersentasekan sebesar $85 \%$ dari total populasi (BPS, 2015). Fakta ini menyiratkan bahwa zakat di Indonesia memiliki potensi besar dan dapat berkontribusi dalam mengurangi kemiskinan. Berkaitan dengan potensi zakat di Indonesia ada beberapa studi penelitian yang membahas terkait hal tersebut di antaranya studi penelitian PIRAC, PEBS FEUI, dan penelitian yang dilakukan oleh UIN Syarif Hidayatullah Jakarta dan beberapa penelitian lainnya.

Studi penelitian yang dilakukan oleh BAZNAS, menyatakan potensi zakat nasional pada tahun 2015 sudah mencapai Rp 286 triliun. Angka ini dihasilkan dengan menggunakan metode ekstrapolasi yang mempertimbangkan pertumbuhan PDB pada tahun-tahun sebelumnya. Perkembangan zakat di Indonesia meningkat secara signifikan sejak UU No. 38/1999 disahkan oleh pemerintah (Outlook Zakat Indonesia, 2018).

Data zakat, infaq, dan sedekah (ZIS) di Indonesia menunjukkan bahwa terdapat kenaikan jumlah penghimpunan zakat dari tahun 2002 hingga 2016 dapat dilihat dalam Tabel 1.1.

Tabel 1 Jumlah Penghimpunan ZIS di Indonesia (Tahun 2002-2018)

\begin{tabular}{crr}
\hline Tahun & $\begin{array}{c}\text { Jumlah ZIS (Miliar } \\
\text { Rupiah) }\end{array}$ & $\begin{array}{r}\text { Pertumbuhan } \\
(\%)\end{array}$ \\
\hline 2002 & 68,39 & $0,00 \%$ \\
2003 & 85,28 & $24,70 \%$ \\
2004 & 150,09 & $76,00 \%$ \\
2005 & 295,52 & $96,90 \%$ \\
2006 & 373,17 & $26,28 \%$ \\
2007 & 740 & $98,30 \%$ \\
2008 & 920 & $24,32 \%$ \\
2009 & $1.200,00$ & $30,43 \%$ \\
2010 & $1.500,00$ & $25,00 \%$ \\
2011 & $1.729,00$ & $15,27 \%$ \\
2012 & $2.212,00$ & $27,94 \%$ \\
2013 & $2.639,00$ & $19,30 \%$ \\
2014 & $3.300,00$ & $25,05 \%$ \\
2015 & $3.653,27$ & $10,71 \%$ \\
2016 & $5.017,29$ & $37,34 \%$ \\
2017 & $6.224,37$ & $24,05 \%$ \\
2018 & $8.100,00$ & $31,80 \%$ \\
\hline (Sumber : Outlook Zakat Indonesia 2019) & & \\
& &
\end{tabular}


Sampai dengan tahun 2018, LAZNAS Yatim Mandiri sudah memiliki 45 kantor Cabang yang tersebar di 14 provinsi seluruh Indonesia. Data penghimpunan LAZNAS Yatim Mandiri dapat dilihat pada Tabel 2 .

Tabel 2 Data Penghimpunan Donasi Yatim Mandiri (Tahun 2002-2018)

\begin{tabular}{|c|c|c|c|}
\hline PERIODE & TOTAL & $\begin{array}{l}\text { Pertumbuha } \\
\text { Rp }\end{array}$ & $\%$ \\
\hline 2008 & 11.329 .000 .000 & 0 & 0 \\
\hline 2009 & 19.762 .000 .000 & 8.433 .000 .000 & $74,44 \%$ \\
\hline 2010 & 30.895 .000 .000 & 11.133 .000 .000 & $56,34 \%$ \\
\hline 2011 & 43.153 .551 .514 & 12.258 .551 .514 & $39,68 \%$ \\
\hline 2012 & 56.138 .309 .136 & 12.984 .757 .622 & $30,09 \%$ \\
\hline 2013 & 70.686 .254 .610 & 14.547 .945 .474 & $25,91 \%$ \\
\hline 2014 & 75.975 .398 .392 & 5.289 .143 .782 & $7,48 \%$ \\
\hline 2015 & 80.926 .139 .787 & 4.950 .741 .395 & $6,52 \%$ \\
\hline 2016 & 86.796 .584 .985 & 5.870 .445 .198 & $7,25 \%$ \\
\hline 2017 & 91.614 .037 .226 & 4.817 .452 .241 & $5,55 \%$ \\
\hline 2018 & 103.143 .232 .888 & 11.529 .195 .661 & $12,58 \%$ \\
\hline
\end{tabular}

Dari data Tabel 2 terlihat pertumbuhan donasi LAZNAS Yatim Mandiri di lima tahun terakhir, yaitu tahun 2014 sampai dengan 2018 yang cenderung berada di kisaran pertumbuhan 6,5 miliar rupiah atau $\pm 8 \%$ per tahun. Dengan kata lain, pertumbuhannya hanya satu digit per tahun. Padahal di lima tahun sebelumnya, khususnya tahun 2008 sampai dengan 2013 pertumbuhan rata-rata mencapai 11,8 miliar atau pertumbuhan bisa mencapai dua digit per tahun (45\%).

Jika dibandingkan tingkat penghimpunan donasi LAZNAS Yatim Mandiri dengan penghimpunan dana zakat secara nasional (market share) maka terlihat market share LAZNAS Yatim Mandiri memiliki tren yang menurun. Hal ini dapat dilihat pada Gambar 1.1.

Adanya penurunan market share, meningkatnya persaingan serta ancaman tingginya tingkat persaingan baru di industri perzakatan, perlu

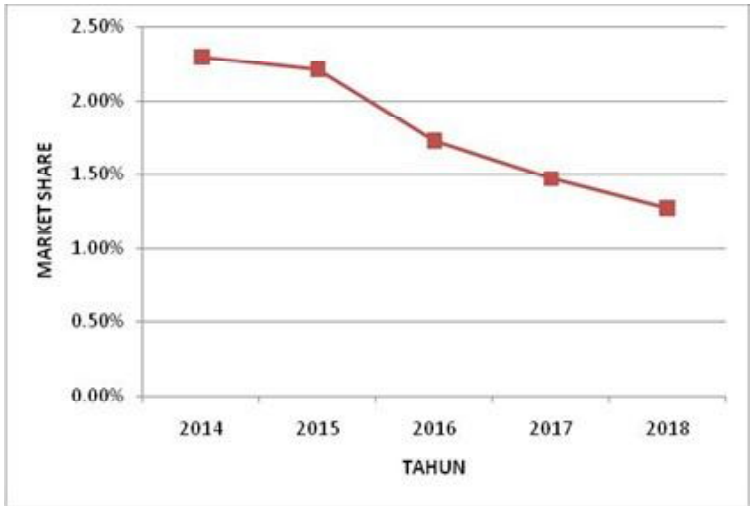

Gambar 1

diantisipasi LAZNAS Yatim Mandiri agar tetap bisa menjaga daya saingnya serta dapat memenangkan persaingan bisnis. Dengan kondisi tersebut, lembaga dituntut untuk merumuskan strategi pemasaran yang tepat untuk dapat mengatasi masalah tersebut. Hasil penelitian Moghaddam dan Foroughi (2012) menyebutkan bahwa dalam lingkungan yang kompetitif, strategi pemasaran bagi sebuah organisasi sangat penting dalam meningkatkan pangsa pasarnya.

Dengan menggunakan framework strategi diamond penulis mengusulkan penelitian dengan topik Formulasi Strategi Pemasaran Lembaga Amil Zakat Nasional Yatim Mandiri" untuk meningkatkan market share di era persaingan ke depan.

\section{Rumusan Masalah}

Berdasarkan pemaparan latar belakang dan identifikasi permasalahan tersebut maka rumusan masalah penelitian adalah bagaimana formulasi strategi pemasaran yang tepat bagi LAZNAS Yatim Mandiri untuk meningkatkan market share di era persaingan ke depan menggunakan strategi Diamond?

\section{Tujuan Penelitian}

Dari perumusan masalah yang telah diuraikan tersebut maka tujuan yang ingin dicapai 
dalam penelitian ini adalah merancang formulasi strategi pemasaran yang tepat bagi LAZNAS Yatim Mandiri untuk meningkatkan market share di era persaingan ke depan menggunakan model strategi Diamond.

\section{B. TINJAUAN PUSTAKA STRATEGI PEMA- SARAN}

Strategi merepresentasikan bagaimana suatu perusahaan melakukan aktivitasnya untuk menghasilkan nilai yang unik secara berbeda dibandingkan dengan pesaingnya. Agar perusahaan dapat unggul dari pesaingnya maka perusahaan harus dapat memberikan nilai yang lebih besar kepada konsumennya, baik dengan produk berbeda atau harga (biaya) yang lebih rendah. Atau mungkin mengombinasikan keduanya. Dari penciptaan nilai untuk konsumen tersebut maka perusahaan dapat memperoleh keuntungan (profitabilitas) yang lebih tinggi (Thompson et al., 2016: 4).

\section{Strategi Diferensiasi}

Dari beberapa pengertian diferensiasi yang diutarakan oleh para pakar pemasaran tersebut dapat kita simpulkan bahwa diferensiasi itu adalah suatu cara ataupun proses dengan memperhatikan aspek perusahaan terkait untuk membedakan diri dari para pesaing untuk menambah nilai ataupun manfaat pada merek atau perusahaan untuk memberikan value yang terbaik bagi konsumen ataupun pelanggan kita dengan menggunakan teknologi maupun strategi pemasaran.

\section{Diferensiasi Produk}

Diferensiasi produk adalah kegiatan memodifikasi produk menjadi menarik. Diferensiasi ini memerlukan penelitian pasar yang cukup serius agar bisa benar-benar berbeda dan diperlukan pengetahuan tentang produk desain. Diferensiasi produk juga dapat diartikan sebagai upaya dari sebuah perusahaan untuk membedakan produknya dari produk pesaing dalam suatu sifat yang membuatnya lebih diinginkan. Semua perusahaan mencari beberapa jenis keunggulan.

\section{Diferensiasi Jasa}

Jika produk fisik tidak mudah didiferensiasi, kunci keberhasilan dalam persaingan terletak pada beberapa hal berikut.

a. Kemudahan pemesanan: mengacu pada seberapa mudah pelanggan dapat melakukan pemesanan ke perusahaan.

b. Pengiriman: mengacu pada seberapa baik produk atau jasa diserahkan kepada pelanggan. Penyerahan itu mencakup kecepatan, ketepatan, dan perhatian selama proses pengiriman.

c. Pemasangan: mengacu pada pekerjaan yang dilakukan untuk membuat produk tertentu beroperasi di lokasi yang direncanakan. Kemudahan pemasangan menjadi titik jual yang sebenarnya, terutama bila pasar sasaran adalah orang baru dalam teknologi.

d. Pelatihan pelanggan: mengacu pada pelatihan para pegawai pelanggan untuk menggunakan peralatan dari penjual secara tepat dan efisien.

e. Konsultasi pelanggan: mengacu pada pelayanan data, sistem informasi, dan saran yang diberikan penjual kepada pembeli.

f. Pemeliharaan dan perbaikan: merupakan program pelayanan perusahaan untuk membantu pelanggan menjaga produk yang mereka beli senantiasa dalam kondisi kerja yang baik.

\section{Risiko Strategi Diferensiasi}

Setiap kegiatan tidak terlepas dari risiko. Salah satunya adalah strategi diferensiasi yang 
strategi diferensiasi yang memiliki beberapa risiko sebagai berikut.

a. Sekiranya pembeli tidak melihat keunikan yang signifikan pada barang tersebut, strategi diferensiasi amat dengan mudah dapat ditandingi oleh harga murah. Diferensiasi gagal menimbulkan efek perbaikan kualitas bagi pembeli barang tersebut, misalnya pada peningkatan status. Manajemen tidak mampu mendeteksi kebutuhan riil konsumen. Dalam hal ini, biasanya manajemen hanya memberikan tekanan pada atribut pokok produk yang berwujud saja.

b. Strategi diferensiasi juga tak hendak menghasilkan keuntungan yang optimum jika imitasi terhadap barang tersebut dapat dengan mudah dan cepat dilakukan. Dengan demikian, diferensiasi hampir selalu menuntut keunikan yang berkelanjutan yang berjangka relatif panjang. Di samping itu, pilihan strategi diferensiasi juga mengandung risiko yang inheren terhadap kemungkinan kecilnya pangsa pasar yang dikuasai.

c. Strategi diferensiasi juga tidak mudah diterapkan jika perbedaan antara harga premium yang ditawarkan dengan harga barang pesaing yang menggunakan strategi keunggulan biaya rendah terlampau jauh. Pembeli bukan tak mungkin bersedia kehilangan kepuasan karena memutuskan tak membeli barang yang terdiferensiasi sebagai akibat kemungkinan penghematan yang bias dilakukan karena membeli barang lain yang jauh lebih murah. Kesalahan ini lebih mudah terjadi karena perusahaan melakukan diferensiasi secara berlebihan.

\section{Perumusan Strategi}

Retina Sri Sedjati (2015) menyebutkan bahwa perumusan strategi terdiri dari proses penyusunan langkah-langkah perusahaan di masa yang akan datang dalam rangka membangun visi dan misinya, menentukan tujuan strategi, serta merancang strategi untuk mencapai tujuan tersebut demi menghadirkan customer value yang terbaik.

Hambrick and Frederickson mengatakan bahwasanya strategi memiliki beberapa elemen yang membentuk suatu kesatuan yang koheren. Strategi merupakan sebuah konsep yang penting, terintegrasi, dan berorientasi eksternal tentang bagaimana bisa mencapai tujuannya.

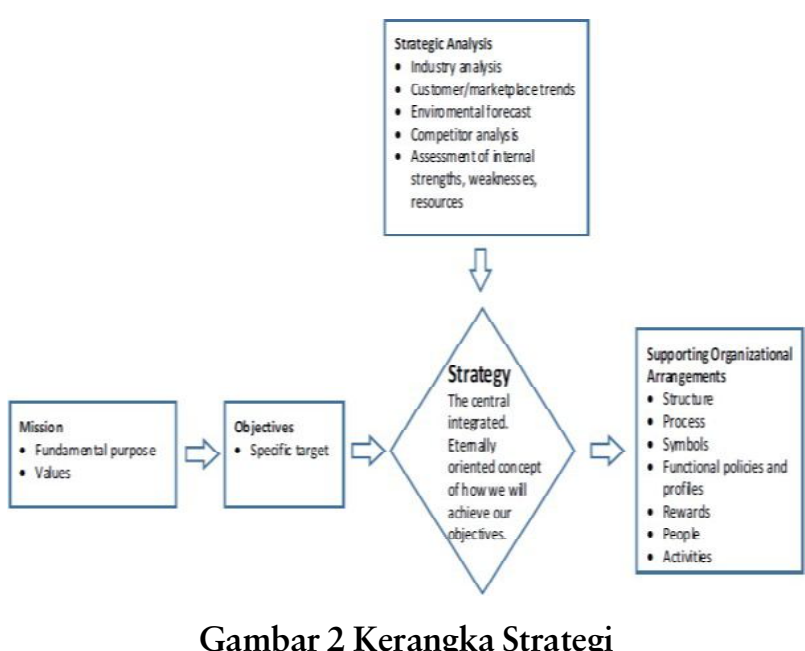

Gambar 2 menjelaskan kerangka strategi di mana misi dan tujuan perusahaan merupakan landasan dan pedoman dalam menyusun strategi. Di samping itu, dalam perumusan strategi juga harus memperhatikan analisis strategis berupa analisis industri, tren konsumen dan pasar, peramalan kondisi lingkungan, analisis pesaing, analisis kekuatan, kelemahan, dan sumber daya internal.

\section{Strategi Diamond}

Donald C. Hambrick dan James W. Fredrickson (2005) merumuskan sebuah framework desain sebuah strategi yang disebut strategi Diamond. Strategi Diamond memiliki lima elemen penting untuk menghasilkan jawaban 
dari pertanyaan yang mencakup arena, vehicles, differentiations, staging, dan economic logic.

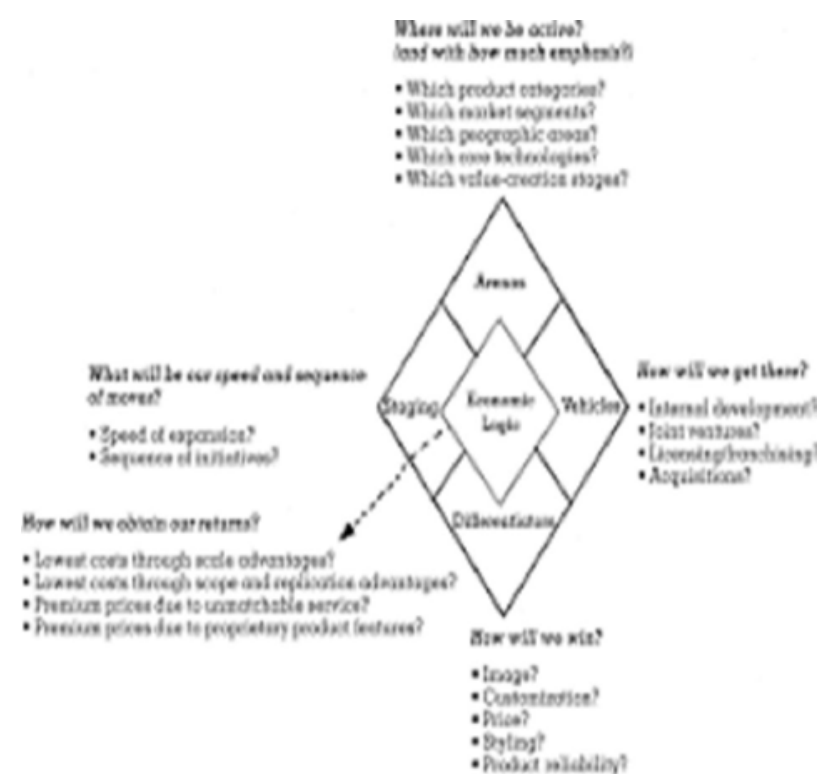

Sumber: Are You Sure Have Strategy (Hambrick \& Frederickson, 2005:p54)

Gambar 3 Lima Elemen Strategi Diamond

\section{Kerangka Konseptual Penelitian}

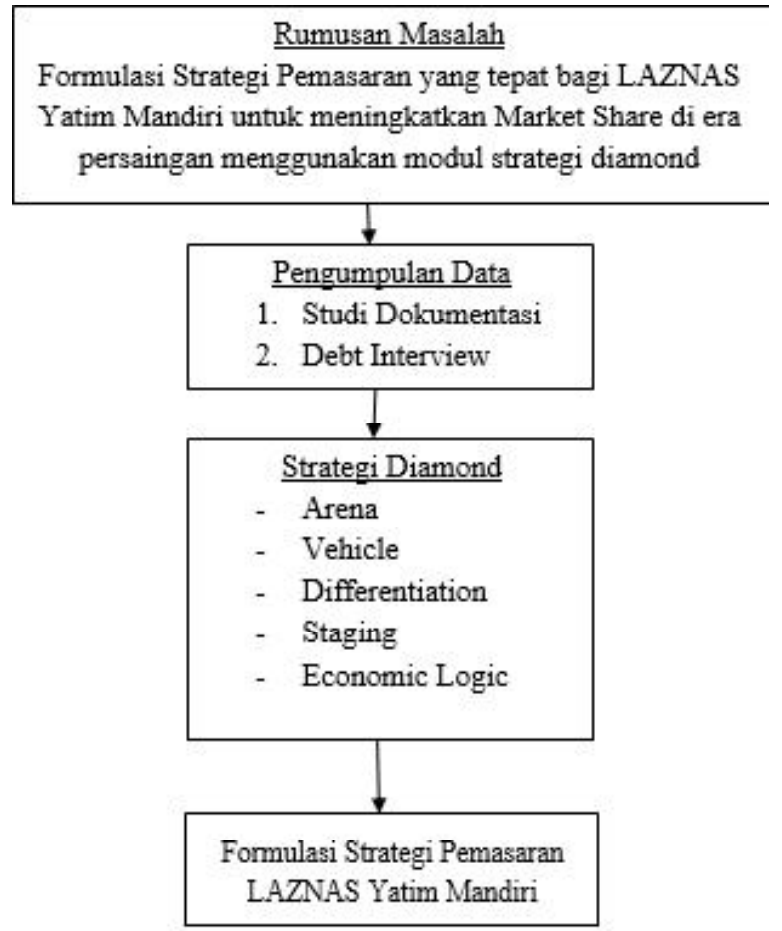

Gambar 4 Kerangka Penelitian

\section{METODE PENELITIAN}

Penelitian ini menggunakan metode penelitian kualitatif dengan pendekatan case study (studi kasus). Tujuan dari metodologi ini bukan suatu generalisasi tetapi pemahaman terhadap suatu masalah. Ada beberapa jenis penelitian kualitatif, yaitu (a) etnografi (ethnography); (b) studi kasus (case study); (c) studi dokumen; (d) pengamatan alami (natural observation); (e) fenomenologi (phenomenology); (f) teori dasar (grounded theory); (g) biografi (biography); (h) studi sejarah (bistorical research).

Penelitian ini menggunakan metode studi kasus di mana menurut Yin (2015), studi kasus merupakan strategi yang lebih cocok apabila pokok pertanyaan penelitian berkenaan dengan bagaimana atau mengapa, atau bila peneliti hanya memiliki sedikit peluang untuk mengontrol peristiwa-peristiwa yang akan diselidiki, atau bilamana fokus penelitian mengarah pada fenomena yang terjadi pada masa kini (bukan historis) dalam konteks kehidupan yang nyata.

Di antara keuntungan penggunaan metode studi kasus, seluruh entitas organisasi yang diteliti dapat diinvestigasi secara mendalam, teliti, dan detail. Hal ini memungkinkan peneliti melakukan penelitian dengan saksama dan mengidentifikasi hubungan antar-fungsi, individu, atau entitas. Oleh karena itu, penelitian studi kasus membutuhkan kerja sama yang baik dari organisasi yang diteliti.

Di antara tiga jenis studi kasus yang dikemukakan Yin (2015), penelitian yang dilakukan ini termasuk studi kasus eksploratoris yang bersifat menggali lebih dalam dari berbagai sumber tentang fenomena yang diteliti. Peneliti bermaksud menggali strategi pemasaran LAZNAS Yatim Mandiri berdasarkan tantangan dan kondisi lingkungan yang dihadapi. 


\section{Jenis Data dan Sumber Data}

Jenis dan sumber data yang digunakan dalam penelitian ini sebagai berikut.

1. Data primer merupakan data yang belum pernah dipublikasikan yang berhubungan dengan penelitian ini. Data primer merupakan data hasil observasi yang dialami dan kemudian dicatat sesuai kondisi fakta kebenaran dengan menyesuaikan waktu pencatatan dan peristiwa terjadi (Walliman, 2001:197). Data primer dinilai teruji kebenarannya (reliabel) jika langsung dikumpulkan oleh peneliti. Peneliti mendapatkan data langsung dari sumber pertama berupa transkrip hasil wawancara berdasarkan pertanyaan yang diajukan.

2. Data sekunder, yakni data yang telah diperoleh atau pernah dipublikasikan sebelumnya. Peneliti mendapatkan data sekunder berasal dari buku, surat kabar, laporan, jurnal, website, maupun berbagai sumber yang dapat melengkapi penelitian yang relevan.

\section{Metode Pengumpulan Data}

Proses pengumpulan data yang dilakukan peneliti adalah sebagai berikut.

\section{Studi Dokumentasi}

Peneliti mengumpulkan berbagai informasi dari bermacam-macam sumber informasi tertulis atau dokumen. Data yang dihimpun penulis berasal dari internal dan eksternal lembaga. Data internal lembaga meliputi antara lain (1) profil lembaga; (2) laporan perusahaan; (3) data hasil analisis SWOT dan matriks IE lembaga. Sedangkan data-data yang berasal dari eksternal lembaga di antaranya data atau ulasan tentang industri zakat, jurnal, pustaka, serta berbagai catatan tertulis tentang berbagai kegiatan yang berhubungan dan relevan dengan penelitian.

\section{Wawancara}

Proses pengumpulan data dengan melakukan tanya jawab langsung secara tatap muka dengan narasumber penelitian. Pada penelitian ini menggunakan wawancara mendalam (in-depth interview) yaitu bertanya dengan langsung bertatap muka dengan informan atau objek dari penelitian ini dan dilakukan dengan terstruktur, yaitu pengumpulan data dapat dilakukan dengan pertanyaan yang sudah disiapkan dan juga dapat membawa instrumen sebagai pedoman wawancara. Sehingga dalam proses wawancara mendalam ini perlu disiapkan key informan yang akan diwawancarai dan kisi-kisi wawancara.

\section{Teknik Pengorganisasian dan Analisis Data}

Miles dan Hubermen (1984) mengemukakan bahwa aktivitas dalam analisis data kualitatif dilakukan secara interaktif dan berlangsung terus menerus sampai tuntas sehingga datanya jenuh. Ukuran kejenuhan data ditandai dengan tidak diperolehnya lagi data atau informasi baru. Aktivitas dalam analisis meliputi reduksi data (data reduction), penyajian data (data display) serta penarikan kesimpulan dan verifikasi (conclusion drawing/verification).

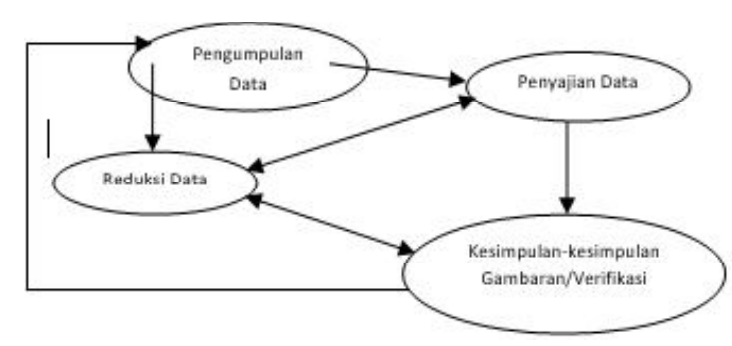

Gambar 5 Bagan Model Analisis Miles dan Huberman

\section{Reduksi Data}

Reduksi data dalam pengertian yang luas bisa diartikan sebagai proses penyempurnaan data, 
pengurangan data yang kurang perlu dan tidak relevan, maupun penambahan data yang dianggap masih kurang. Data yang sudah proses reduksi akan memberikan gambaran yang jelas dan mempermudah untuk melakukan pengumpulan data selanjutnya. Reduksi data dapat menggunakan peralatan elektronik seperti komputer. Dengan reduksi data, peneliti merangkum, mengambil data yang penting, membuat kategorisasi, dan membuang data yang tidak penting.

\section{Penyajian Data}

Penyajian data adalah proses pengumpulan informasi yang disusun berdasar kategori atau pengelompokan yang diperlukan. Penyajian data dapat berbentuk naratif, grafik, matriks, network, dan chart. Penyajian data diarahkan agar data hasil reduksi tersusun dan terorganisasi sehingga semakin mudah dipahami dan dapat merencanakan kerja penelitian selanjutnya.

\section{Penarikan Kesimpulan}

Penarikan kesimpulan/verifikasi meru-pakan proses perumusan makna dari hasil penelitian yang diungkapkan dengan kalimat yang singkatpadat dan mudah dipahami serta dilakukan dengan cara berulang kali melakukan peninjauan mengenai kebenaran dari kesimpulan tersebut, khususnya berkaitan dengan relevansi dan konsistensinya terhadap judul, perumusan masalah, dan tujuan penelitian.

\section{Pengujian Kualitas Data}

Pada penelitian kualitatif keakuratan data adalah sangat penting. Data yang salah akan menghasilkan kesimpulan yang salah, demikian pula data yang sah akan menghasilkan kesimpulan yang benar.
Triangulasi adalah cara untuk menentukan aspek keabsahan suatu data. Triangulasi yang digunakan dalam penelitian ini adalah triangulasi sumber data yang dilakukan dengan mencocokkan kebenaran atau kesamaan data yang diberikan oleh informan satu dengan informan lainnya, pada penelitian ini triangulasi dari pihak internal adalah dengan wawancara kepada para direksi LAZNAS Yatim Mandiri, dan untuk pihak eksternal adalah para donatur LAZNAS Yatim Mandiri.

\section{HASIL DAN PEMBAHASAN}

Dari hasil wawancara dengan para narasumber diperoleh data-data sebagaimana tertuang dalam Tabel 3.

Tabel 3 Ringkasan Elemen Strategi Diamond LAZNAS Yatim Mandiri

\begin{tabular}{|c|c|c|}
\hline & Elemen Strategi & \\
\hline 1 & \multicolumn{2}{|l|}{ Arena } \\
\hline $\mathrm{a}$ & Which market segments? & $\begin{array}{l}\text { - Ritel } \\
\text { - Corporate }\end{array}$ \\
\hline $\mathrm{b}$ & Which geographic area? & $\begin{array}{l}\text { - Domestic } \\
\text { - Global }\end{array}$ \\
\hline c & Which product category? & $\begin{array}{l}\text { Program pemberdayaan anak } \\
\text { yatim }\end{array}$ \\
\hline 2 & \multicolumn{2}{|l|}{ Vehicle (how we will get there) } \\
\hline & \multicolumn{2}{|l|}{ Pasar Domestik } \\
\hline & Internal development & $\begin{array}{l}\text { - Pembukaan Kantor Cabang } \\
\text { - Pengembangan sumber } \\
\text { daya manusia } \\
\text { - Pengembangan teknologi } \\
\text { digital dalam pengelolaan } \\
\text { system administrasi, } \\
\text { keuangan dan pemasaran }\end{array}$ \\
\hline & Strategic Partnership & $\begin{array}{l}\text { - Kemitraan dengan berbagai } \\
\text { kelompok masyarakat } \\
\text { dalam kegiatan fundraising } \\
\text { - Kerjasama dengan fintech } \\
\text { dalam negeri }\end{array}$ \\
\hline & \multicolumn{2}{|l|}{ Pasar Global } \\
\hline & Internal development & $\begin{array}{l}\text { - Mengembangkan website } \\
\text { dan social media } \\
\text { berbahasa asing } \\
\text { - Merekrut para relawan, } \\
\text { yaitu warga Indonesia yang } \\
\text { sudah menjadi warga } \\
\text { negara asing yang tinggal } \\
\text { di negara sasaran }\end{array}$ \\
\hline & Strategic Partnership & $\begin{array}{l}\text { - Strategic partnership } \\
\text { dengan NGO multi } \\
\text { nasional } \\
\text { - Mengembangkan } \\
\text { kerjasama fintech multi } \\
\text { nasional } \\
\end{array}$ \\
\hline
\end{tabular}




\begin{tabular}{|l|l|l}
\hline 3 & Differentiators & \multicolumn{2}{l}{} \\
\hline & Product & $\begin{array}{l}\text { Holistic support program } \\
\text { bagi pemberdayaan anak- } \\
\text { anak yatim }\end{array}$ \\
\hline 4 & Staging & $\begin{array}{l}\text { Tahap I : Konsolidasi } \\
\text { Pasar Domestik } \\
\text { - Tahap II : Elkspansi Pasar } \\
\text { Global }\end{array}$ \\
\hline & $\begin{array}{l}\text { What will be our speed and } \\
\text { sequence }\end{array}$ & \multicolumn{1}{|c}{} \\
\hline 5 & Economic Logic & $\begin{array}{l}\text { Peningkatan } \\
\text { Penghimpunan Donasi } \\
\text { Melalui Inovasi Produk } \\
\text { Penyaluran Donasi }\end{array}$ \\
& How will we obtain our return & $\begin{array}{l}\text { Efisiensi biaya melalui } \\
\text { Inovasi Penghimpunan } \\
\text { Donasi }\end{array}$ \\
\hline
\end{tabular}

Sumber: diolah penulis dari hasil pengumpulan data

\section{Pembahasan Formulasi Strategi Diamond}

Untuk memahami langkah-langkah yang akan dilakukan dalam menyusun strategi pemasaran LAZNAS Yatim Mandiri maka akan digunakan frame work strategi diamond yang dikemukakan oleh Hambrick dan Federickson (2005), yakni dengan menerjemahkan lima elemen yang dibutuhkan dalam rangka mengevaluasi tiap sasaran untuk dapat mencapai tujuan lembaga.

\section{Arena}

Keputusan strategis yang paling penting yang diambil organisasi adalah di arena mana organisasi akan beraksi. Arena ini mencakup pilihan segmen pasar, wilayah geografi, dan produk yang ditawarkan.

\section{a. Segmen Pasar}

Saat ini, LAZNAS Yatim Mandiri lebih banyak fokus pada donatur perorangan (ritel). Selanjutnya, LAZNAS Yatim Mandiri akan memperluas pasar dengan menyasar segmen corporate.

\section{b. Wilayah geografi}

Pada segmentasi geografi pengelompokan dilakukan berdasarkan faktor geografinya, seperti berdasarkan daerah asal atau tempat tinggal konsumen. Jadi dengan segmentasi ini, LAZNAS Yatim Mandiri memperoleh kepastian ke mana atau di mana produk ini harus dipasarkan.

Saat ini, LAZNAS Yatim Mandiri masih melayani donatur domestik (dalam negeri Indonesia) dengan membuka layanan di 45 kantor cabang yang terkoordinasi dalam tiga regional. Regional I meliputi wilayah Provinsi Jawa Timur yang terdiri dari 20 kantor cabang, regional II meliputi Provinsi Jawa Tengah, Yogyakarta, Kalimantan, dan Sulawesi yang terdiri dari 12 kantor cabang, serta regional III meliputi Provinsi DKI Jakarta, Jawa Barat, Sumatera Utara, Sumatera Selatan, Kepulauan Riau, dan Lampung yang terdiri dari 13 kantor cabang.

\section{c. Produk yang ditawarkan}

Produk adalah setiap apa saja yang bisa ditawarkan di pasar untuk mendapatkan perhatian, permintaan, pemakaian, atau konsumsi yang dapat memenuhi keinginan atau kebutuhan.

Mengelola unsur produk termasuk perencanaan dan pengembangan produk atau jasa yang tepat untuk dipasarkan dengan mengubah produk atau jasa yang ada dengan menambah dan mengambil tindakan yang lain yang memengaruhi bermacam-macam produk atau jasa yang dihasilkan.

LAZNAS Yatim Mandiri mengelola program-program penyaluran donasi dengan sasaran fokus kepada anak-anak yatim, yang dapat dikelompokkan sebagai berikut: pendidikan, kesehatan, sosial kemanusiaan, dakwah, dan pemberdayaan ekonomi. Program-program tersebut diarahkan dan diintegrasikan dengan tujuan agar anak-anak yatim mampu mandiri (memiliki penghasilan sendiri).

Langkah pertama untuk mengembangkan arena adalah memastikan LAZNAS Yatim Mandiri memiliki produk yang kuat. Diperlukan 
kepastian bahwa produk/program LAZNAS Yatim Mandiri tersebut dibuat dengan mempertimbangkan visi misi lembaga. Tingkat penerimaan terhadap program LAZNAS Yatim Mandiri harus benar-benar menjadi prioritas penting sehingga harapan munculnya awareness dan keterlibatan, partisipasi, serta bentuk dukungan dapat diberikan oleh para donatur.

Para donatur adalah orang-orang yang tidak sekadar ingin mendonasikan dengan ketulusan niat sebagai salah bentuk pengabdian mereka kepada Tuhannya, tetapi mereka ingin barang yang dibeli bisa memberikan rasa kebanggaan, turut memiliki/self-belonging terhadap program yang dijalankan. Bagaimana program yang ada tersebut benar-benar menjadi fokus output/sasaran penerima manfaat dari LAZNAS Yatim Mandiri? Menjawab pertanyaan- pertanyaan ini akan membantu menentukan pesan yang tepat untuk men-delivered, mendeskripsikan pemasaran program LAZNAS Yatim Mandiri.

Nilai yang ditanamkan pada produk lebih penting daripada kemampuan produk itu sendiri. Dengan kata lain, LAZNAS Yatim Mandiri harus fokus terhadap benefit dari produk tersebut, alih-alih mengenai fitur-fiturnya. Nantinya, setiap fitur harus dikembangkan untuk suatu tujuan yang akan memberikan manfaat/benefit bagi pelanggan. LAZNAS Yatim Mandiri harus memiliki produk yang inovatif atau setidaknya satu produk yang bisa memecahkan tantangan bisnis secara umum.

\section{Vehicles}

Setelah menentukan arena di mana organisasi akan dijalankan, langkah berikutnya adalah bagaimana cara menuju arena tersebut. Beberapa cara yang bisa dipertimbangkan, di antaranya pengembangan internal, akuisi, join venture, partnering, dan sebagainya. Beberapa pilihan strategi yang bisa digunakan LAZNAS Yatim Mandiri adalah sebagai berikut.

\section{a. Pasar domestik}

Untuk mengembangkan pasar domestik LAZNAS Yatim Mandiri menggunakan dua cara.

1. Pengembangan internal, yaitu dengan melakukan hal-hal sebagai beikut.

a. Pembukaan kantor cabang baru

Penentuan cabang baru akan ditentukan dengan potensi dan peluang yang dimiliki oleh sebuah wilayah. Sinkronisasi antara cabang menjadi penting untuk mencapai tujuan, ditambah dengan kerjasama dan saling pengertian antar-cabang yang berada di dalam satu wilayah regional.

Ekspansi dibagi dalam sejumlah wilayah besar (provinsi atau kumpulan sejumlah kabupaten) yang bertanggung jawab atas sejumlah wilayah yang lebih kecil. Hal ini dimaksudkan untuk mempermudah koordinasi antar-wilayah dan menetapkan sejumlah kebijakan yang sesuai dengan kondisi yang ada.

b. Pengembangan sumber daya manusia

Pengembangan sumber daya manusia diarahkan untuk memenuhi kebutuhan pengembangan lembaga. Memahami kepentingan, aspirasi, dan kemampuan karyawan adalah kunci dalam menentukan pilihan dan posisi strategis LAZNAS Yatim Mandiri.

Pengembangan karyawan secara terus menerus melalui on-the-job-training maupun program pelatihan lainnya merupakan suatu hal yang sangat penting bagi pertumbuhan sumber daya manusia.

Pengembangan teknologi informasi dalam pengelolaan sistem administrasi, keuangan, dan pemasaran. 
Berkembangnya teknologi informasi dan komunikasi serta semakin tingginya pengguna internet di Indonesia memberi dampak yang sangat positif bagiperkembangan pengelolaan zakat di Indonesia. Pemanfaatan teknologi informasi untuk menunjang pengelolaan zakat yang lebih baik sangat dibutuhkan. Oleh karena dengan pemanfaatan teknologi informasi itu pengelolaan yang amanah, profesional, transparan, dan akuntabel serta memperhatikan kepatuhan syariah (sharia compliance) dapat terwujud.

Pengembangan teknologi diharapkan dapat memberikan kemudahan dalam melakukan transaksi pembayaran donasi dan kemudahan dalam memperoleh informasi penyaluran donasi, berbagai pengetahuan keagamaan, dan informasi lainnya yang dibutuhkan donatur.

Di samping itu, penggunaan internet dalam pengumpulan, penyaluran, pengontrolan, dan pelaporan zakat akan meningkatkan kuantitas dan kualitas pemberdayaan dana zakat sehingga dana zakat dapat lebih meningkatkan kesejahteraan masyarakat miskin. Secara konseptual, peran teknologi internet dalam pengumpulan dana zakat dari muzakki akan memperluas daya jangkau amil dalam mengakses muzakki, begitu juga sebaliknya dengan teknologi internet muzakki akan lebih mudah menyalurkan zakatnya kepada amil. Sementara itu, penggunaan teknologi internet dalam menyalurkan dana zakat akan mempermudah amil mengontrol program dan monitoring perkembangan masyarakat miskin yang terlibat dalam program sehingga pemanfaatan dana zakat dan proses peningkatan kesejahteraan masyarakat miskin lebih terpantau dengan baik. Dari perspektif amil zakat, penggunaan teknologi internet terutama untuk administrasi, pelaporan, dan informasi lembaga amil akan meningkatkan kredibilitas dan profesionalitas kelembagaan dan personel amil itu sendiri sehingga lembaga amil dapat semakin dipercaya oleh muzakki dan masyarakat secara umum.

\section{Meningkatkan aktivitas promosi melalui me- dia online (website, social media, dan mar- ketplace)}

Promosi merupakan suatu kegiatan yang berupaya memberi tahu pasar sasaran tentang produk yang tepat. Promosi meliputi penjualan tatap muka (personal selling), penjualan masal (mass selling), dan promosi penjualan (sales promotion).

Promosi yaitu kegiatan mengomunikasikan suatu produk kepada masyarakat agar produk itu dikenal dan ujung-ujungnya diminati, dibeli, atau dikonsumsi oleh masyarakat itu sendiri. Promosi atau komunikasi pemasaran adalah sarana di mana LAZNAS Yatim Mandiri berusaha menginformasikan, membujuk, dan mengingatkan konsumen secara langsung maupun tidak langsung tentang produk dan merek yang dijual. Intinya, promosi atau komunikasi pemasaran mempresentasikan "suara" LAZNAS Yatim Mandiri dan mereknya serta merupakan sarana di mana LAZNAS Yatim Mandiri dapat membuat dialog dan membangun hubungan dengan konsumen.

Promosi merupakan salah satu variabel dalam bauran pemasaran yang sangat penting dilaksanakan oleh YATIM MANDIRI dalam memasarkan produk jasa. Kegiatan promosi bukan saja berfungsi sebagai alat komunikasi antara LAZNAS Yatim Mandiri dan donatur, melainkan juga sebagai alat untuk memengaruhi donatur dalam berbagai kegiatan.

\section{Strategic Partnership}

Partnering atau kolaborasi/kerjasama adalah bentuk interaksi, kompromi beberapa elemen 
yang terkait baik individu, lembaga dan atau pihak-pihak yang terlibat secara langsung dan tidak langsung yang menerima akibat manfaat. Nilai-nilai yang mendasari sebuah kolaborasi adalah tujuan yang sama, kesamaan persepsi, kemauan untuk berproses, saling memberikan manfaat, serta kejujuran.

Strategic partnership ini dapat dilakukan dengan cara sebagai berikut.

1. Membangun kemitraan dengan Lembaga Amil Zakat lain, utamanya lembaga yang belum memiliki izin operasional sebagai lembaga amil zakat yang dikeluarkan oleh Kementerian Agama Republik Indonesia.

2. Membangun kemitraan dengan fundraising tingkat kabupaten, kecamatan, sampai kelurahan.

3. Membangun kemitraan fundraising di instansi-instansi.

4. Bermitra dengan lembaga, organisasi sosial kemasyarakatan, atau organisasi wanita yang bergerak di barisan akar rumput (PKK, dasa wisma, dan lain-lain).

\section{Pasar Global}

Selain itu, untuk menjangkau pasar global, LAZNAS Yatim Mandiri mengembangkan cara sebagai berikut.

1. Internal development

a. Mengembangkan website dan social media berbasis bahasa internasional, diawali dengan bahasa Inggris dan nantinya terus ditambah dengan bahasa asing lainnya sesuai dengan target negara yang dituju.

b. Merekrut relawan warga negara Indonesia yang bekerja di negara asing dan mereka sudah menjadi warga negara di mana mereka tinggal sehingga memudahkan dalam proses sosialisasinya.
2. Strategic partnership

a. Kemitraan dengan NGO di negara asing juga dijalin agar dapat memudahkan menyalurkan donasi dan menghimpun donasi.

b. Kerjasama dengan fintech multinasional untuk memberikan kemudahan bagi para donatur melakukan pembayaran donasi.

\section{Differentiators}

Diferensiasi bagi LAZNAS Yatim Mandiri adalah upaya untuk memproduksi dan memasarkan suatu produk dengan karakteristik tertentu yang khas yang pada akhirnya mengakibatkan produk tersebut dianggap unik dan bahkan eksklusif oleh donatur. LAZNAS Yatim Mandiri dapat berusaha memilih salah satu atau beberapa atribut produk yang dianggap penting oleh konsumen dan memosisikan produk dengan atribut yang dianggap penting tersebut. Diferensiasi produk juga dapat diartikan sebagai upaya dari LAZNAS Yatim Mandiri untuk membedakan program dari pesaing dalam suatu sifat yang membuatnya lebih diinginkan oleh para donatur. Semua lembaga zakat akan mencari beberapa jenis keunggulan kompetitif yang dapat membedakan produk mereka dari produk yang lainnya.

Untuk menjadi pembeda dengan Lembaga Amil Zakat, Yatim Mandiri menawarkan produk ke masyarakat berupa holistic support program bagi anak-anak yatim, yaitu berbagai program penyaluran donasi yang ditujukan bagi anakanak yatim mulai dari usia dini sampai dengan mandiri. Program untuk anak yatim konsisten dilakukan oleh Yatim Mandiri sejak awal berdiri tahun 1994. Program utama adalah di bidang pendidikan, yaitu memberikan beasiswa bagi anak-anak yatim dari jenjang sekolah dasar hingga perguruan tinggi. Di samping itu, juga mendirikan dan mengelola pendidikan sekolah mene- 
ngah dan perguruan tinggi. Program Pendidikan ini didukung penuh dengan program kesehatan dan pemberdayaan ekonomi sehingga mengantarkan anak-anak yatim mampu mandiri. Hal inilah yang menjadi pembeda Yatim Mandiri dengan lembaga yang serupa.

Adapun Strategi yang dibangun dalam holistic support program LAZNAS Yatim Mandiri ini adalah sebagai berikut.

1 Pemberdayaan kelompok (community empowerment)

a. Pembentukan iklim, suasana partisipasi secara umum dimulai dari tingkat top management hingga bottom management sampai menjadi nilai yang inheren pada setiap aktivitas perencanaan dan tindakan dalam program pemberdayaan anak-anak yatim.

b. Meningkatkan desentralisasi dan kemandirian kantor-kantor cabang LAZNAS Yatim Mandiri dalam pengambilan keputusan agar masalah dan penyelesaiannya memiliki akar empiris yang kuat. Hal ini meningkatkan efektivitas dan efisiensi dalam upaya pemecahan masalah yang berkaitan dengan pembinaan anak-anak yatim.

c. Adanya Keberlanjutan program dalam memelihara maupun meningkatkan hasil program dan proyek tersebut.

d. Penyediaan pendamping, fasilitator, dan peer to peer discussion dari luar yang dilibatkan untuk menambah spirit dan akselerasi untuk gerakan pemberdayaan anak-anak yatim.

2. Perluasan kesempatan (promoting opportunity)

a. Penyusunan kebijakan internal untuk memberikan kesempatan bagi LAZNAS Yatim Mandiri untuk memperoleh pengetahuan organisasi, pengelolaan LAZNAS Yatim Mandiri. b. Fasilitasi prasarana dan sarana fisik di bidang transportasi, komunikasi, kesehatan, dan akses pemodalan yang diarahkan untuk meningkatkan dan mempercepat kemandirian anak-anak yatim.

3. Pengembangan perlindungan sosial (enhancing social security)

a. Pemberian perlindungan, assurance, dan legalitas kepada anak yatim agar bisa digunakan sebagai modal kerja dan kemudahan akses lainnya.

b. Pembentukan atau penguatan kelompok anak-anak yatim dengan kelompok-kelompok sejenis yang memiliki tujuan yang sama sehingga memanfaatkan akses ekonomi, politik, sosial, dan budaya bagi peningkatan kualitas hidup dan kesejahteraan sosial anak-anak yatim.

c. Pembangunan jaringan kerjasama antara individu, lembaga/kelompok swadaya masyarakat, lembaga pemerintahan, dan lembaga ekonomi. Jaringan berguna untuk memperluas batas kemampuan individu atau kelompok serta sebagai pertahanan dari krisis yang mungkin menghadang secara mendadak.

Diferensiasi produk layanan yang fokus kepada program pemberdayaan anak yatim akan membuat produk/jasa LAZNAS lebih melekat di konsumen/stakeholder. Sebagai informasi perbedaan yang ada akan membuat konsumen mengingat jasa yang menjadi konsentrasi LAZNAS Yatim mandiri karena adanya point of interest yang kita miliki yaitu keunikan yang tidak dimiliki oleh lembaga yang lain. Dari sisi pemasaran maka tenaga marketing sampai kepada decision maker LAZNAS Yatim mandiri memiliki kepercayaan diri sekaligus eksplorasi persuasif yang lebih kaya saat mereka berhadapan dengan donatur/calon donatur. Diferensiasi akan membuat 
produk LAZNAS Yatim Mandiri terlihat lebih baik dibandingkan dengan produk lembaga amil zakat lainnya.

\section{Staging}

Elemen ini menentukan urutan kecepatan langkah strategis yang dipilih. Dari hasil wawancara didapatkan dua tahapan strategi, adapun langkah-langkahnya adalah sebagai berikut.

\section{a. Tahap I: konsolidasi pasar domestik}

Pada tahap konsolidasi pasar domestik ini diharapkan LAZNAS Yatim Mandiri dapat meningkatkan pangsa pasarnya sehingga mampu masuk dalam jajaran market leader di industri zakat dalam negeri. Upaya akan dilakukan adalah melakukan evaluasi dan menetapkan target capaian market share dalam rentang waktu 20202024.

Gambar 4 Target Capaian Market Share dalam Lima Tahun ke Depan

\begin{tabular}{|c|c|}
\hline TAHUN & MARKET SHARE \\
\hline 2020 & $2.00 \%$ \\
\hline 2021 & $2.25 \%$ \\
\hline 2022 & $2.50 \%$ \\
\hline 2023 & $2.75 \%$ \\
\hline 2024 & $3.00 \%$ \\
\hline
\end{tabular}

Sumber: diolah oleh penulis dari penghimpunan data

Peningkatan capaian market share ini didasarkan pada capaian market share dari kompetitor dalam hal ini RUMAH ZAKAT (RZ). Dengan demikian, dalam fase ini ditentukan bahwa rentang pertumbuhan market share adalah minimal 2\% dan maksimal 3\% dalam kurun waktu lima tahun.

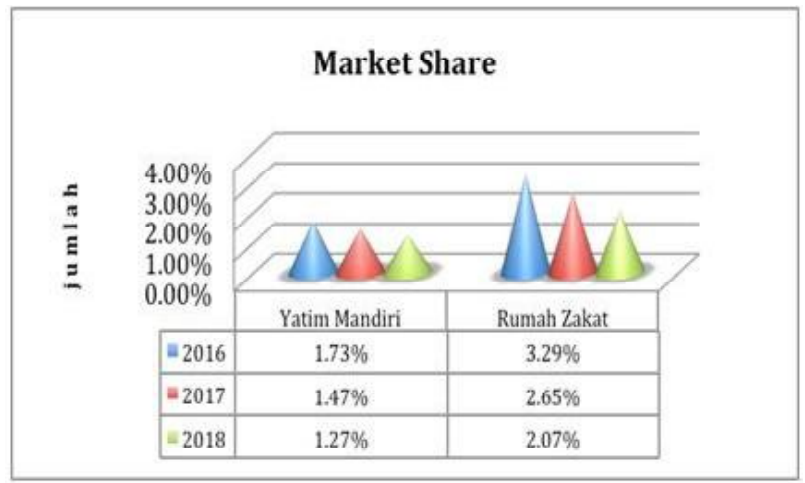

Sumber: diolah oleh penulis dari penghimpunan data

\section{Gambar 6 Perbandingan Market Share LAZNAS} Yatim Mandiri dengan Rumah Zakat

Strategi untuk kegiatan penghimpunan donasi yang dilakukan adalah sebagai berikut.

1. Melakukan penetrasi pasar di wilayah regional III, khususnya Kota Jakarta, Bogor, Depok, Tangerang, dan Bekasi.

2. Melakukan pengembangan pasar, yaitu menambah cabang di kota-kota yang potensial, khususnya kota yang berdekatan dengan cabang yang sudah ada dan sudah memiliki donatur rutin.

3. Meningkatkan aktivitas promosi melalui media online (website, social media, dan marketplace).

4. Mengadakan kerjasama pembayaran donasi melalui aplikasi perbankan dan uang elektronik.

5. Membangun kemitraan dengan berbagai kelompok masyarakat.

a. Kemitraan dengan lembaga amil zakat lain, utamanya lembaga yang belum memiliki izin operasional sebagai lembaga amil zakat yang dikeluarkan oleh Kementerian Agama Republik Indonesia.

b. Kemitraan dengan fundraising tingkat kabupaten, kecamatan, sampai kelurahan.

c. Membangun kemitraan fundraising di instansi-instansi. 
d. Bermitra dengan lembaga, organisasi sosial kemasyarakatan, dan organisasi wanita yang bergerak di barisan akar rumput (PKK, dasa wisma, dan lain-lain).

6. Melakukan pengembangan segmen pasar, yaitu menjangkau segmen corporate dan menengah atas.

Sedangkan strategi konsolidasi untuk program penyaluran donasi adalah sebagai berikut.

1. Melakukan penetrasi pasar untuk penyaluran donasi dengan menambah dan memeratakan program-program penyaluran di cabangcabang yang sudah berjalan.

2. Melakukan inovasi produk dengan meningkatkan kemasan program penyaluran agar lebih menarik para donatur.

3. Mendirikan dan mengembangkan lembaga pendidikan formal dari pendidikan menengah hingga perguruan tinggi.

\section{Tahap II: Going Global Market}

Pada tahap ini diharapkan LAZNAS Yatim Mandiri mampu menjangkau donatur yang berada di luar negeri, terutama donatur dari warga negara Indonesia yang tinggal di luar negeri.

Secara umum yang dapat dilakukan oleh LAZNAS Yatim Mandiri adalah giat melakukan sosialisasi lembaga dan program, khususnya kepada pekerja asal Indonesia. Terutama menjelang dan selama bulan Ramadhan pengiriman dari dalam hal ini akan semakin membuka jalan dan semakin dekat dengan stakeholder di luar negeri. Dengan begitu harapannya mereka mempercayakan pembayaran dana zakatnya via LAZNAS Yatim Mandiri bekerjasama dengan kedutaan besar Indonesia serta perhimpunan pelajar Indonesia di luar negeri.

LAZNAS Yatim Mandiri juga dapat melakukan kemitraan dengan pelbagai lembaga swa- daya masyarakat di luar negeri, utamanya yang bergerak dalam bidang crowd funding.

Mengutip kompas.com 23/04/2018 jumlah tenaga kerja Indonesia yang bekerja di luar negeri, berdasarkan survei World Bank ada sekitar sembilan juta per akhir 2017. Lima puluh persennya ada di Malaysia, 13 persen di Saudi Arabia, sepuluh persen di China atau Taipei, dan di negara-negara lain. LAZNAS Yatim Mandiri memiliki peluang untuk menjadikan mereka sebagai donatur dalam lima tahun ke depan dengan target orang satu persen atau sekitar 90.000 .

Secara khusus, strategi untuk kegiatan penghimpunan donasi yang dilakukan adalah sebagai berikut.

1. Mengembangkan website dan social media berbasis bahasa internasional, diawali dengan bahasa Inggris dan nantinya terus ditambah dengan bahasa asing lainnya sesuai dengan target negara yang dituju.

2. Mengembangkan sistem pembayaran donasi antar-negara guna memudahkan para donatur melakukan transaksi pembayaran donasi antar-negara.

3. Merekrut para relawan, yaitu para warga Indonesia yang sudah menjadi warga negara asing yang tinggal di negara tujuan.

4. Kemitraan dengan NGO di negara asing juga dijalin agar dapat memudahkan menyalurkan donasi dan menghimpun donasi.

Sedangkan strategi penyaluran donasi, yang dilakukan adalah sebagai berikut.

1. Pengembangan produk, akan dikembangkan program-program yang lebih luas dalam menangani isu-isu kemanusiaan, seperti trafficking (perdagangan anak), kekerasan dalam rumah tangga, bencana alam, kelaparan, kemiskinan, dan sebagainya. 
2. Pengembangan pasar wilayah penyaluran donasi dengan lebih meningkatkan sebaran anakanak yatim sebagai penerima program dari seluruh Indonesia, terutama di pelosok dan tempat yang kurang terjangkau, serta diikuti dengan pembangunan pusat-pusat pendidikan, kesehatan, dan pemberdayaan ekonomi.

\section{Economic Logic}

Economic logic merupakan elemen terakhir dalam framework strategi diamond. Elemen ini meringkas bagaimana empat elemen lainnya diintegrasikan untuk memaksimalkan tujuan organisasi yang ingin dicapai. Menurut Hambrick (2001) economic logic untuk organisasi profit dapat mengambil bentuk skala ekonomi, ruang lingkup ekonomi, harga premium, atau beberapa kombinasi dari ini. Untuk organisasi nirlaba, economic logic mencerminkan seberapa baik organisasi mencapai misi dan visinya serta melayani para pemangku kepentingan utamanya. Dalam hal ini pemangku kepentingan utama LAZNAS Yatim Mandiri adalah donatur dan penerima bantuan (mustahik/anak yatim).

Donatur merupakan pemangku kepentingan utama sekaligus sumber dana utama bagi LAZNAS Yatim Mandiri. Penguatan dan perluasan donatur akan menjadi pilar utama dan pengembangan LAZNAS Yatim Mandiri hingga di level dunia. Hal ini dapat tercipta dengan optimalisasi teknologi informasi dan internet dalam proses pembangunan awareness, perekrutan donatur, hingga pembangunan loyalitas donatur. Di antara contoh program yang telah dicanangkan berupa pengembangan sistem pengumpulan donasi yang lebih memudahkan donatur dengan memanfaatkan layanan e-money serta peningkatan social media marketing dan crowd funding.

Hubungan yang semakin kuat dengan donatur perlu diiringi dengan penguatan inovasi layan- an program bantuan pemberdayaan yatim serta ekspansi kebermanfaatannya hingga ke pelosokpelosok daerah dan luar negeri. Hal ini dapat meningkatkan donasi dari donatur rutin serta masyarakat secara umum.

Dari hasil wawancara dan analisis, penulis merangkum bahwa kebijakan strategi yang dapat menjadi economic logic bagi pengembangan LAZNAS Yatim Mandiri ke depan, yaitu penerapan strategi peningkatan penghimpunan donasi melalui inovasi produk penyaluran donasi serta efisiensi biaya melalui inovasi penghimpunan donasi.

Hal ini dapat dilakukan dengan terus melakukan evaluasi penilaian kinerja dalam menjalankan kegiatan operasionalnya dalam melayani donatur dan menyalurkan donasi dalam program pemberdayaan anak-anak yatim.

Langkah-langkah yang harus di jalankan dalam kerangka economic logic ini adalah sebagai berikut.

a. Peningkatan penghimpunan donasi melalui inovasi produk penyaluran donasi. Program pengembangan bagi anak yatim harus lebih banyak dieksplorasi dan ragam variasi sesuai dengan tuntutan masa depan dan tentu saja harapan dari lembaga YATIM MANDIRI sehingga mampu menarik/memberikan daya pikat dalam peningkatan penghimpunan donasi bagi donatur atau calon donator.

Strategi ini dapat dilaksanakan dengan cara menambah program baru tetapi masih saling berhubungan dengan program yang sudah ada baik program bidang pendidikan, kesehatan, maupun ekonomi.

Untuk meningkatkan donasi melalui inovasi produk, YATIM MANDIRI akan melakukan beberapa program sebagai berikut.

1. Pelatihan life skill bagi 10.000 YATIM selama periode satu tahun. Adapun biaya per yatim 
yang dialokasikan untuk pelatihan life skill adalah $\mathrm{Rp} 2.000 .000,00$ sehingga dalam program ini alokasi biaya yang diharapkan mampu didapat dari donatur adalah $\mathrm{Rp}$ 20.000.000.000,00 (dua puluh miliar rupiah).

2. Mobil sehat keliling sebanyak 50 unit dalam periode lima tahun. Dengan alokasi dana Rp 500.000.000,00/unit sehingga biaya untuk pengadaan program secara keseluruhan ini adalah sebesar Rp 25.000.000.000,00 (dua puluh lima miliar rupiah).

3. Pemberdayaan Program BUNDA BISA (perluasan penerima manfaat). Dalam program ini akan diberikan bantuan kelompok BUNDA BISA dengan alokasi biaya sebesar $\mathrm{Rp}$ 25.000.000.000,00 (dua puluh lima miliar rupiah) untuk target 5000 BUNDA BISA selama dalam kurun waktu lima tahun.

Sedangkan strategi dalam economic logic yang berikutnya adalah efisiensi biaya melalui inovasi penghimpunan donasi.

Upaya untuk memilih alternatif pengembangan dan promosi akan produk LAZNAS Yatim Mandiri dengan prinsip efisiensi, mengurangi cost yang berlebihan dan cenderung tidak terkontrol pada aktivitas menghimpun dan mengoleksi donatur sehingga hasil donasi lebih maksimal. Salah satu upaya untuk memaksimalkan hasil donasi dengan prinsip pengendalian dan efisiensi adalah bagaimana memaksimalkan media promosi lewat teknologi informasi yang telah dimiliki oleh LAZNAS Yatim Mandiri.

Pada aspek penghimpunan donasi dan dalam upaya mengoptimalkan penghimpunan donasi, LAZNAS Yatim Mandiri perlu terus melakukan sosialisasi dan edukasi melalui kampanye zakat secara berkelanjutan. Selain melaksanakan kampanye donasi di dunia nyata, kampanye juga perlu dilakukan di dunia maya (internet) meng- ingat saat ini perkembangan pengguna internet di Indonesia sangat tinggi. Oleh karena, dengan pemanfaatan teknologi informasi itu pengelolaan yang amanah, profesional, transparan, dan akuntabel serta memperhatikan kepatuhan syariah (sharia compliance) dapat terwujud. Saat ini LAZNAS Yatim Mandiri telah membuat situs website resmi, aplikasi, serta membuat akunakun resmi di beberapa aplikasi media sosial.

Berikutnya adalah fungsi amil yang diharapkan di tahun mendatang mengalami penurunan seiring dengan efisiensi biaya melalui inovasi penghimpunan donasi. Meningkatnya kesadaran masyarakat untuk berdonasi harus pula diimbangi oleh pengelolaan amil dalam menggerakkan ini. Metode yang diambil harus sesuai syariah termasuk dengan metode digital. Penggunaan metode digital harus tetap memiliki unsur amanah dan transparan.

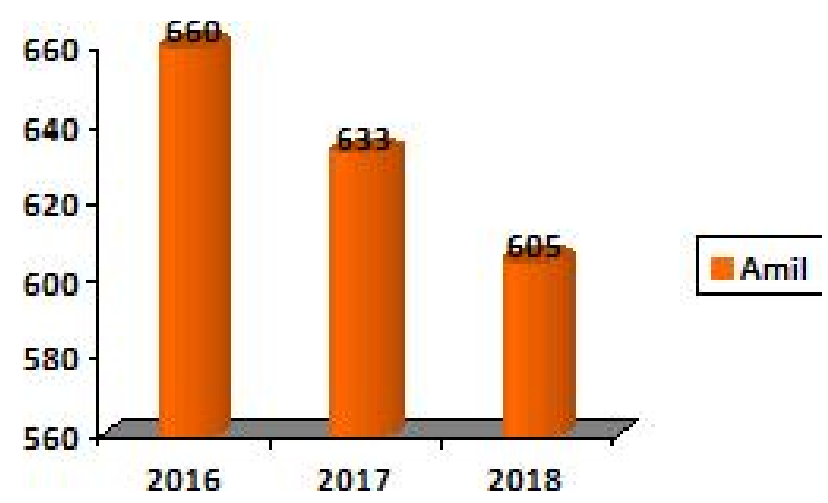

Sumber: diolah peneliti dari hasil pengumpulan data

\section{Gambar 7 Penurunan Jumlah Amil dalam Periode 2016-2018}

Efisiensi ini sangat penting dilakukan sebagai bentuk pengendalian dan peningkatan performance YATIM MANDIRI. Adapun yang akan dilakukan adalah besaran persentase efisiensi BOPO akan menurun dalam lima tahun ke depan. 
Tabel 5 \% BOPO dalam Periode 2015-2018

\begin{tabular}{|c|c|}
\hline TAHUN & $\%$ BOPO \\
\hline 2015 & $27.33 \%$ \\
\hline 2016 & $21,98 \%$ \\
\hline 2017 & $27.02 \%$ \\
\hline 2018 & $22.86 \%$ \\
\hline
\end{tabular}

Sumber: diolah penulis

Diketahui bahwa dalam rentang waktu 2015-2018 besaran efisiensi ini adalah rata-rata sebesar 24,8\%. Harapannya bahwa dalam kurun waktu 2020-2024 dapat terjadi penurunan BOPO minimal 18\% dan maksimal 20\%.

\section{E. KESIMPULAN}

Berdasarkan hasil analisis dan pembahasan maka kesimpulan yang dapat diambil dari penelitian serta formulasi strategi pemasaran LAZNAS Yatim Mandiri berdasarkan frame work strategi diamond adalah sebagai berikut.

1. Arena, where will we be active and with how much emphasis?

Tantangan yang muncul adalah bagaimana memformulasikan strategi yang akan digunakan pada tahap awal ini yang difokuskan pada segmen pasar ritel di dalam negeri dan ke depan pada segmen corporate serta pasar luar negeri. Pentingnya mempertahankan donatur aktif pada pasar ritel adalah sebuah keharusan di samping upaya membangun kepercayaan pada donatur untuk menaikkan jumlah donasinya. Keberadaan Kantor cabang diharapkan membantu mempermudah jangkauan dan layanan purna-donasi kepada para donatur sehingga kekuatan kepercayaan dan service excellent menjadi daya pikat.
Untuk pasar domestik strategi yang dilakukan adalah melakukan penetrasi pasar dari 45 cabang yang dimiliki oleh LAZNAS Yatim Mandiri. Adapun daerah tersebut adalah yang berada di wilayah Jabodetabek. Penetrasi ini dilakukan akan dilakukan dengan aktif dan progresif. Sedangkan untuk wilayah Jawa Barat dan Jawa Tengah akan dilakukan perluasan pasar bagi keberadaan LAZNAS Yatim Mandiri. Di wilayah ini akan di buka kantor cabang sekaligus aktif melakukan partnership/kolaborasi dengan lembaga sejenis.

Untuk pasar Global, kehadiran LAZNAS Yatim Mandiri akan secara aktif membuka cabang di beberapa negara. Di antaranya adalah Malaysia dan Brunei untuk wilayah Asia Tenggara, untuk Asia Timur akan dikembangkan di Hongkong dan Jepang, sedangkan untuk Timur Tengah adalah Negara Arab Saudi dan Mesir akan menjadi tujuan ke depan.

\section{Vehicle, how will we get there?}

Formulasi strategi yang akan digunakan adalah sebagai berikut. (a) Pengembangan internal dengan melakukan pembukaan kantor cabang yang diperkuat dengan pengembangan sumber daya manusia dan teknologi digital dalam pengelolaan administrasi, keuangan, dan pemasaran. (b) Melakukan kerjasama strategis (partnering) dengan lembaga amil zakat lain. Untuk pengembangan internal, LAZNAS Yatim Mandiri akan membuka 55 kantor cabang baru di kabupaten/ kota yang mempunyai tingkat pertumbuhan ekonomi 5\%/tahun. Untuk peningkatan sumber daya manusia, LAZNAS Yatim Mandiri akan melakukan serangkaian training sesuai dengan kebutuhan posisi dan jabatan yang ada dalam LAZNAS Yatim Mandiri. Tak lupa akan dilakukan peningkatan kinerja sumber daya internal dengan peng- 
aturan jenjang karier yang lebih sistematis dan terukur. Keberadaan amil abru sebagai ujung tombak akan dilakukan serangkaian program peningkatan performance melalui amil development program. Sedangkan penataan kantor cabang akan dilakukan pula dengan upaya penataan formasi kantor cabang dan kantor pusat.

Bahwa dalam fase ini, pengembangan teknologi digital dalam pengelolaan administrasi yang terintegrasi dengan keuangan sangat penting untuk dilakukan. Keberadaan sistem yang terintegrasi/platform menjadi jawaban atas kebutuhan dan tantangan tersebut. Untuk strategi partnership akan dilakukan upaya membangun kerjasama, kemitraan, kolaborasi dengan fintech dalam negeri dan luar negeri, pengembangan website, dan peran sosial media berbahasa asing. Kemudahan dalam memberikan donasi sekaligus inovasi dalam pengembangan cara berdonasi dengan mudah tanpa ribet adalah dengan bekerja sama dengan sistem payment gateway (OVO, DANA, LINK AJA, GO PAY, dan lain-lain).

\section{Differentiation, how we will?}

Formulasi strategi yang digunakan adalah memanfaatkan keunggulan produk LAZNAS Yatim Mandiri sebagai lembaga amil zakat yang memberikan holistic support penyaluran donasi kepada anak yatim dengan berbagai program yang ditujukan bagi anak-anak yatim mulai dari usia dini sampai dengan mandiri (memiliki penghasilan sendiri) dalam lingkup pendidikan, ekonomi, dan sosial.

\section{Staging, what will be speed and sequence of moves?}

Formulasi strategi yang dilakukan adalah dengan dua tahapan sebagai berikut.
1. Tahap I dengan melakukan konsolidasi pasar domestik

Upaya akan dilakukan adalah melakukan evaluasi dan menetapkan target capaian market share dalam rentang waktu 2020-2024.

Peningkatan capaian market share ini didasarkan pada capaian market share dari competitor dalam hal ini RUMAH ZAKAT (RZ). Dengan demikian, dalam fase ini ditentukan bahwa rentang pertumbuhan market share adalah minimal 2\% dan maksimal 3\% dalam kurun waktu lima tahun.

2. Tahap II dengan melakukan ekspansi ke pasar global

Pada fase ini akan dilakukan perluasan donasi ke mancanegara. Adapun targetnya adalah para pekerja dan pelajar yang di luar negeri. Dari jumlah sembilan juta masyarakat Indonesia yang berada di luar negeri maka yang menjadi target sasaran adalah 1\% pada lima tahun depan.

5. Economic logic, how will returns be obtained?

Formulasi strategi yang akan digunakan untuk tahap ini adalah dengan melakukan peningkatan penghim-punan donasi melalui inovasi produk penyaluran donasi serta efisiensi biaya melalui inovasi penghimpunan donasi.

Untuk meningkatkan donasi melalui inovasi produk, LAZNAS Yatim Mandiri akan melakukan beberapa program sebagai berikut.

1. Pelatihan life skill bagi 10.000 yatim selama periode satu tahun. Dalam program ini alokasi biaya yang diharapkan mampu didapat dari donatur yaitu Rp 20.000.000.000,00 (dua puluh miliar rupiah).

2. Mobil sehat keliling sebanyak lima puluh unit dalam periode satu tahun. Adapun biaya 
untuk pengadaan program ini adalah sebesar Rp 25.000.000.000,00 (dua puluh lima miliar rupiah).

3. Pemberdayaan program BUNDA BISA (perluasan). Dalam program ini akan diberikan bantuan kelompok BUNDA BISA dengan alokasi biaya sebesar Rp 25.000.000.000,00 (dua puluh lima miliar rupiah).

Sedangkan strategi dalam economic logic yang berikutnya adalah efisiensi biaya melalui inovasi penghimpunan donasi.

Efisiensi ini sangat penting dilakukan sebagai bentuk pengendalian dan peningkatan performance LAZNAS Yatim Mandiri. Adapun yang akan dilakukan adalah besaran persentase efisiensi BOPO akan menurun dalam lima tahun ke depan. Diketahui bahwa dalam rentang waktu 2015-2018 besaran efisiensi ini adalah 24,8\%. Harapannya bahwa dalam kurun waktu 20202024 dapat terjadi penurunan BOPO minimal $18 \%$ dan maksimal 20\%.

\section{G. IMPLIKASI PENELITIAN}

\section{Implikasi Teori}

Implikasi teori dari penelitian ini adalah dapat memberikan wawasan terkait strategi pemasaran yang ada di LAZNAS Yatim Mandiri, lalu memberikan gambaran terkait LAZNAS Yatim Mandiri, dan memberikan informasi terkait strategi diamond LAZNAS Yatim Mandiri.

\section{Implikasi Praktik}

Implikasi praktik dari penelitian ini adalah dapat memberikan formulasi strategi pemasaran bagi LAZNAS Yatim Mandiri dalam upaya meningkatkan penghimpunan dalam menghadapi persaingan bisnis di industri lembaga amil zakat.

\section{Keterbatasan Penelitian dan Saran Penelitian}

Berikut ini adalah beberapa keterbatasan dan saran yang ada dalam penelitian ini.

1. Penelitian ini tidak mendiskusikan langkah rinci penerapannya, penelitian berikutnya program-program jangka pendek sekaligus dengan time line-nya.

2. Peneliti merupakan bagian dalam organisasi Lembaga Amil Zakat Nasional LAZNAS Yatim Mandiri sehingga meskipun sudah berusaha seobjektif mungkin namun tetap ada kemungkinan bias atas hasil penelitian ini.

3. Berkenaan rencana jangka panjang dalam mengembangkan pasar di Asia dan dunia maka diperlukan penelitian lanjutan untuk mengkaji strategi organisasi pada level korporasi.

\section{F. RUJUKAN}

Agutinova, D.E. 2015. Memahami Metode Penelitian Kualitatif. Yogyakarta: Calpulis.

David, F.R. 2011. Strategic Management: Concept and Cases, 13th Edition. New Jersey: Pearson Education, Inc.

Grant, R.M. 2016. Contemporary Strategy Analysis, 9th Edition. Wiley.

Hill, C.W. \& Jones, G.R. 1995. Strategic Management an Integrated Approach, 3rd Edition. Boston: Houghton Mifflin Company.

Hambrick, D.C. and Fredrickson, J.W. 2005. Are You Sure You Have A Strategy? Academy of Management Executive, Vol. 19, No. 4, 51-62.

Kotler, P. 2005. Manajemen Pemasaran. Jakarta: PT Indeks Kelompok Gramedia.

Lin, C., Tsai, H.-L., Wu, Y.-J., \& Kiang, M. 2012. A Fuzzy Quantitative VRIO-Based Framework for Evaluating Organizational Activities. Journal of Management Decision, 50(8), 1396-1411. 
Magretta, Joan. 2011. Understanding Michael Porter. The Essential Guided to Competition and Strategy. Boston: Harvard Business Review Press.

Moleong, Lexy J. 2000. Metodologi Penelitian Kualitatif. Bandung: PT Remaja Rosdakarya.

Outlook Zakat Indonesia. 2017. Outlook Zakat Indonesia, 2018.

Pearc, J.A. \& Robinson, R.B. 2008. Strategic Management: Formulation, Implementation, and Control, 10th ed. New York: McGraw-Hill.

Pemerintah Republik Indonesia. 2011. UndangUndang Republik Indonesia Nomor 23 Tahun 2011 tentang Pengelolaan Zakat.

Pemerintah Republik Indonesia. 2014. Peraturan Pemerintah Nomor 14 tahun 2014 tentang Pelaksanaan Undang-Undang Nomor 23 Tabun 2011 tentang Pengelolaan Zakat.

Pemerintah Republik Indonesia. 2015. Керutusan Menteri Agama Nomor 333 tahun 2015 tentang Pedoman Pemberian Izin Pembentukan Lembaga Amil Zakat.

Porter, M.E. 1996. What Is Strategy? Harvard Business Review, November-December Reprint Number 96608.
Porter, M.E. 2008. The Five Competitive Forces That Shape Strategy. Harvard Business Review, 86 No. 1, 80-86.

Thompson, A.A., Strickland III, A.J., \& Gamble, J.E. 2010. Crafting and Executing Strategy: The Quest For Competitive Advantage: Concepts and Cases, Seventeenth Edition. McGraw-Hill.

Wandrial, S. 2011. Analisis Internal Perusahaan (Strength \& Weakness) Menggunakan Konsep Resource-Based View of the Firm dengan Kerangka VRIO. Binus Business Review, 2(2), 627-637.

Wheelen, T.L., \& Hunger, J.D. 2012. Strategic Management and Business Policy toward Global Sustainability, 13th Edition. New Jersey: Pearson.

Yulianti, D. 2014. Analisis Lingkungan Internal dan Eksternal dalam Pencapaian Tujuan Perusahaan (Studi Kasus PT Perkebunan Nusantara VII Lampung). Jurnal Sosiologi, 103-114.

Yin, R.K. 2015. Studi Kasus Desain \& Metode. Jakarta: PT. Raja Grafindo Persada.

Zikmund, W.G., Babin, B.J., Carr, J.C., \& Griffin, M. 2013. Business Research Methods, 11th Edition. South Western: Cengage Learning. 